\title{
在宅介護と地域支援の視点から ON PLANNING AND EVALUATION OF みた高齢者住宅の住まい方と平 HOUSE FOR THE AGED FROM THE 面評価 VIEWPOINT OF COMMUNITY AND NURSING AT HOME
}

\section{常広陽子——1 野口孝博 一}

キーワード :

高齢者，居場所，在宅介護，地域支援，戸建住宅，街路側居室

Keywords :

The aged, The living place, Nursing at home, Community, Detached houses, Living space on street

\section{Yoko TSUNEHIRO $-* 1 \quad$ Takahiro NOGUCHI $-* 2$}

This paper aims at studying the state of a future dwelling which considered nursing at home and community. It made clear the aged's consciousness and evaluation to the side of the street in houses. As a result of evaluating the present house plan based on conditions required for people, it turned out to be good for the aged that there is the living place by the side of a street in houses, in community and nursing at home.
1.はじめに一意義・目的

高齢社会の到来に伴い、高齢になっても住み慣れた住宅に住み続 けられるよう、在宅福祉や地域福祉の充実が求められている。一方 で、現在の住宅計画では、住宅内の居住環境の充実を重視し、福祉 サービスの享受しやすさ（特に住宅と外部との関係）は必ずしも十分 に考慮されていない。プライバシーや騒音の問題などから、街路側にあ る居室のイメージは一般的によくないが、これからの高齢社会に対応 しうるよう、社会との接点である住宅の街路側のあり方を見直す必 要がある。将来的に、福祉开ービ入を受けやすく、家族の介護負担を 軽減させる住宅をつくることが高齢社会の住宅計画に必要な条件の 一つと考えられる。

本研究は、戸建住宅に居住する高龄者の居場所（1 日の内で最も 長く[就寝時間を除く]過ごす居室）1）と住宅の街路側のあり方に主 眼をおき、(1)高齢者住宅（高龄者の居住する住宅）の居住実態と(2) 在宅高齢者の住宅の街路側のあり方に対する意識を把握する。(3)在 宅介護と地域支援（地域住民によるサポート）に必要な高齢者住宅の 条件を検討し、(4)その条件を考慮した評価項目を用いて高齢者住宅 の現状評価を試みる。これらを通じて、これからの住宅のあり方を 検討するための新しい計画的視点を提供することを目的とする。

既往研究に、在宅介護及び地域支援のしやすさの観点から住宅の 街路側居室のあり方を取り上げたものはほとんど見られない。関連 する既往の研究としては、高齢者の住生活を明らかにするため住宅 内での拠点性に注目した研究2３３４）や方位観からみた住宅プランに関 する研究 ${ }^{5}$ 、開口部形状に注目した町並みに関する研究 ${ }^{6)}$ などがあ る。また、最近のバリアフリー住宅の傾向に、段差解消などの物理的バ
师の除去に留まらず、外とのつながりを重視する傾向が見られ始め ている7)。平成 12 年の介護保険制度開始に伴い、介護のしやすさや プライバシー問題など心のバリアの除去も考慮され始めているが、それに 対する有効な解決手段はまだ提案されていない状況である ${ }^{8)}$

本研究は、地域のコミュニティー形成や在宅介護の負担軽減など具体的 な利点に着目し住宅の街路側のあり方を見直す点で、これからの住 宅計画に対して意義のある研究である。

\section{2. 調查方法と回答者属性}

築 25 年を経過し、高齢化の進んだ札幌市「もみじ台団地」の戸 建住宅に居住する 60 歳以上の高齢者を対象に、アンケート調査を行った (01 年 9 月)。アンケート配布数は 262 部で回取数は 232 部（回取率 88.5 \%)だった。さらに、要介護認定者（3 軒）を含む 9 軒に対し、ヒアリ

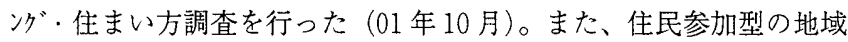
福祉の実態について、地域福祉従事者にヒアリンダを行った 02 年 1 月)。回答者の属性は表1のとおりである。また、年齢や身体状況は ふだんの過ごし方に違いを生み、それによって介護・支援問題に対 する意識が異なると考え、要介護認定の有無と「夏のふだんの過ご し方」注1)を基に回答者の夕イプ 分けを行った。要介護認定を受けて いる回答者を「要介護認定者」、その他を「外出夕亿プ」「家の周囲夕 イプ」「家の中夕イプ」の3つに分け、計 4 タイプに分類した。 表1. 回答者の属性と健康状態

\begin{tabular}{|c|c|c|c|c|c|}
\hline \multicolumn{2}{|c|}{ 年龄 } & \multicolumn{2}{|c|}{ 健康状態(家の中を歩〈時) } & \multicolumn{2}{|c|}{ 家族形態 } \\
\hline $60 \sim 64$ 瓷 & $57 \curlywedge(24.6 \%)$ & 不自由なく歩 & $202 \curlywedge(90.2 \%)$ & 単独世带 & $17 \lambda(7.6$ \\
\hline 前期高跉者 & $116 入(50.0 \%)$ & ゆっくりと歩く & $17 \lambda(7.6 \%)$ & 夫婦のみ & $133 \curlywedge(59.1 \%)$ \\
\hline 嵝期高龄者 & 59 ᄉ (25.4\%) & 補助器具使用 & 3 人 $(1.3 \%)$ & 同居世带 & $27 \lambda(12.0 \%)$ \\
\hline 計 & 232 ᄉ $(100.0 \%$ & 介助必要 & $1 \lambda(0.4 \%)$ & 親と子 & $43 \wedge(19.1)$ \\
\hline 平均年䀫 & 69.5葴 & その他 & 1 人 $(0.4 \%)$ & その他 & $5 \lambda(2.2 \%)$ \\
\hline & & 計 & $224 \lambda(100.0 \%)$ & 計 & $225 \curlywedge(100.0 \%)$ \\
\hline
\end{tabular}

\footnotetext{
${ }^{* 1}$ 札幌市役所 工修

(下006-0012 札㹸市手稲区富丘2-7-4-43)

*2 北海道大学大学院工学研究科 助教授 $\cdot$ 工博

*1 Sapporo City Office, M. Eng.

*2 Assoc. Prof., Graduate School of Eng., Hokkaido University, Dr. Eng.
} 


\section{3.「居場所」の居住実態}

在宅高齡者は住宅の中で一定の居場所をもち、一日の大半を過ご している。回答者の 8 割が「居間」を居場所とし、その滞在平均時 間は夏が 8.4 時間、冬は 9.4 時間と非常に長い。また、居場所と外 との視覚的・空間的なつながりを望んでいる高齢者が大半であるこ とがわかった。回答者の 8 割が居場所から外の景色を「よく眺めて い」て、回答者の 7 割が居場所から直接外と出入りできることにつ いて「便利だからい」と回答している。居場所からの眺めとして

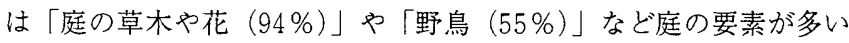

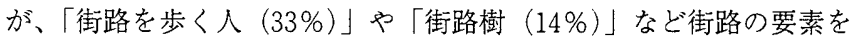
眺めている高齢者もいる。䄈ング調查では、自力で外出不可能な高 齢者には、特に訪問客や街路を歩く人の様子を眺めるのを楽しみと する傾向がみられた。

居場所は南向きの部屋に設けられていることが多く、街路との関 係を意識している高齢者は少ない（表2）。住まい方調査より、方位 よりも在宅介護のしやすさを重視して、北側に街路があるにも関わ らず、街路側に高齢者の居場所を設けている事例がみられた（1軒）。 また、寝室との関係では、「家の中タイプ」や「要介護認定者」のよ うに身体が不自由になるほど、居場所と寝る場所が同じ部屋になる 傾向がみられる(図 1)。住まい方調査事例では、「一体的に使う」が $1 / 9$ 軒、「同じ部屋」が $2 / 9$ 軒あった。

\section{4. 住宅の街路側のあり方に対する意識}

居場所を街路側に設けることについて、全体の12\%が「安心感」 注2の面で、24\%が「楽しさ」注3の面でよいと感じていることがわかっ た（図 2)。特に、自力で外出不可能な「要介護認定者」は、「楽し さ」の面を約 4 割が評価している。また、街路から高龄者の様子を 誢える住宅は、地域住民による高齢者の気軽な安否確認を可能にす る点で、地域支援のしやすさに非常に有効である（地域福祉従事者 ヒアリングより)。

寝室は最もプライベートな居室だと考えられてきたが、介護保険導入 表2.「居場所」と街路の関係

\begin{tabular}{|c|c|c|c|c|c|c|}
\hline & \multicolumn{5}{|c|}{ 街路に対する、住宅内での居場所の位置 } \\
\hline & & 徍路鵙 & 街路と反対側 & 横側 & その他 & 総数 \\
\hline \multirow{3}{*}{$\begin{array}{l}\text { 住宅から } \\
\text { みた街路の } \\
\text { ある方角 }\end{array}$} & 南側 & $68.6 \%$ & $9.7 \%$ & $13.9 \%$ & $8.3 \%$ & 72 人 \\
\hline & 北側 & $5.9 \%$ & $66 \%$ & $17.6 \%$ & $9.8 \%$ & 51 人 \\
\hline & 東·西側 & $8.8 \%$ & $11.8 \%$ & 6 64 . & $14.7 \%$ & \\
\hline
\end{tabular}

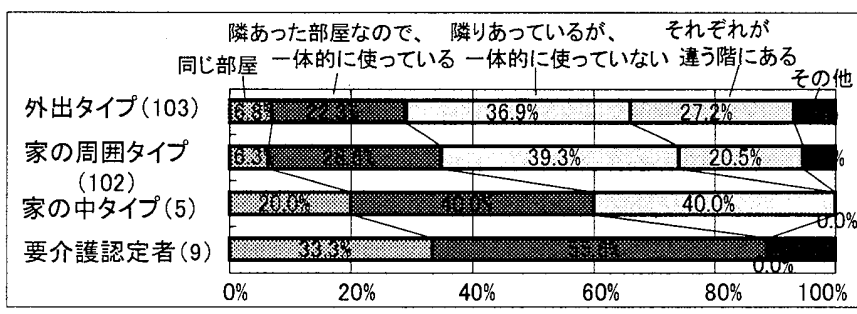

図1.「居場所」と寝室の関係

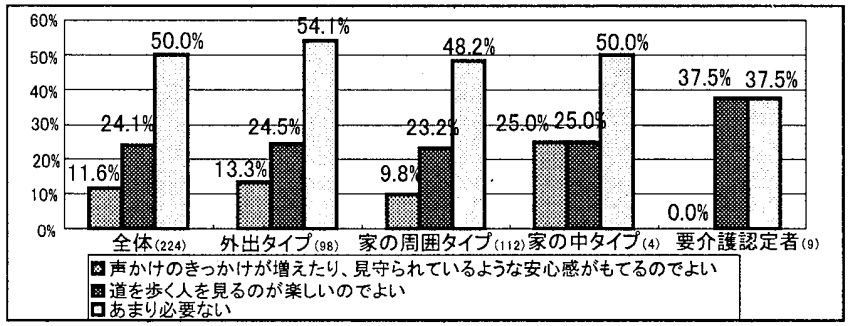

図2.「居場所」を街路側に設けることについての意識
以来、要介護の高齢者の寝室にはへルパーなどが入ってくるため、第 三者との関係という新たな問題に対処しなければならなくなった。 身体が不自由になった時を想定した場合に、寝室を街路側に設ける ことについて回答してもらった結果、「家の中夕イプ」や「要介護認 定者」の場合は「プライバシーを考えると難しい」が皆無で、「外出し やすさ」の面で 4 割がよいと回答した（図 3)。プライバシー問題よりも、 街路側に寝室（兼居場所）があることに帅师を感じていることがわ かる。また、全体の1 割程度が「家族のプライバシーが守られ、ヘル゚ーの 仕事がしやすい」点を評価していることもわかった。現状で介護問 題に直面していない高齢者でも、それに対する事前の対処法として 街路側居室に理解を示すことがわかった。

\section{5. 要介護者のいる住宅にみられる特徴}

「要介護認定者」のいる住宅の 3 軒中 2 軒では、^ルバーが入ること のできる領域（以下、^Nハ・-領域）がその他の家族の生活領域 と分離できる工夫がなされていることがわかった（図 4)。図 4 は、 要介護者の居場所（兼寝室）が街路側にあり、玄関に近接している ため、へル゚ー領域が $22 \mathrm{~m}^{2}$ (20\%/1 階) と少ない。また、へル゚ー領域が $40 \mathrm{~m}^{2}(38 \% / 1$ 階） と比較的多くなるが、廊下を利用して領域分離を 行っている住宅もあった（1軒）。へル゚ーによる介護中でも、その他の 家族の生活は守られるので心理的負担の軽減に慗がっている。また、 寝室と設備の近接傾向がみられた。生理的欲求を満たす他、在宅 介護の負担軽減や介助時にヘ川゚ーと他の家族との動線が交わること を防いでいる。設備を高齢者専用に設置する場合は、最小面積で高 齢者の寝室に配置している。また、共用の場合は面積を十分広くと り、高齢者寝室に近接しながらも他の家族が使用しやすいような動 線の工夫がみられた。その他、庭や街路の様子をよく眺められるよ うベッドや仅を配置したり、街路の様子を見やすくするために常に カーテンを開け放している住宅のように、居場所からの眺めに配虑し ていることがわかった。

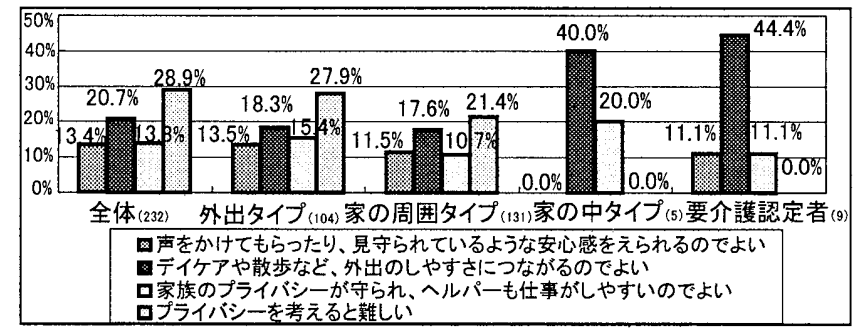

図3.身体が不自由にな時を想定して、寝室を街路側に設けることについての意識

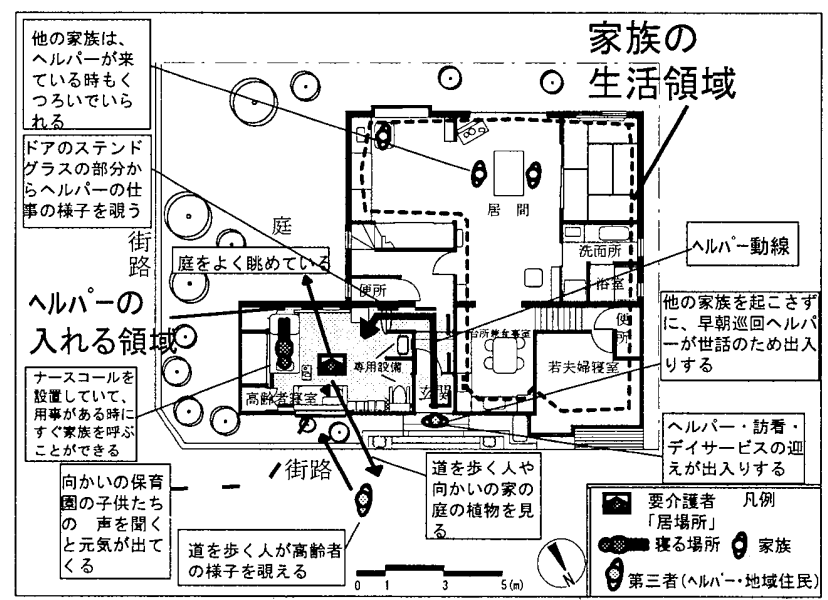

図4. 要介護認定者の居場所が街路側にあり、NW゚-領域の分離が行われている事例 
6. 在宅介護・地域支援のしやすさに関する住宅平面評価

\section{$6-1$. 評価方法}

在宅介護と地域支援の視点から、住宅に改めて必要となる計画条 件を検討した。計 11 個の項目を抽出し（図 5)、この評価項目を用 いて事例評価を行った。対象事例は住まい方調査を行った 9 軒とし、 介護を中心に考えて増改築した 3 軒を「要介護者のために配慮して 増改築された住宅」(以下、A夕イプ) とした（表3）。その他を「街路 が住宅の南側にある住宅」(以下、B多价）と「街路が住宅の南以外 の方角にある住宅」(以下、C多プ) に分類し整理した。高齢者の居 場所が街路との関係に対処しやすいものとして、街路が南側にある 住宅を特に取り上げて分類した。評価項目は、居場所要素（居場所 に必要だと考えられる要素)、垵室要素（身体が不自由になった時、 居場所が寝室と同化することを考慮した要素)、設借要素（設備と の関係で必要な要素) の3つの主な構成要素から成る。具体的には、 (1)～(3)が地域支援のしやすさ、(6)～(11)が在宅介護のしやすさに関わ り、特に(6)(7)8(10)(11)在宅介護でのヘル゚ーと家族の動線分離と家族 の生活領域の確保に関わる項目である。第三者との関わりをもつ1 〜 (3)、(6)〜8、(10)(11)項目について、地域支援や在宅介護の面で非常 に有効である場合を（）、第三者との関わりのない(4)(5)(9)項目につい て有効である場合を○と評価する。(2)のように遮蔽物を避ければ外 部とのつながりを持つことができるなど多少の改善をすればよい場 合や(6)ように「どちらともいえない」場合を、、(3)のように現状 でもある程度の様子を感じることができる有効な状態を○とした。 評洒方法は、調查者がこの評価項目を用いて、住宅平面図（1 階） と調査から得た情報を基に、各住宅について介護や支援のしやすさ に関する「現状評価」と「可能性評価」を行うものである。「現状評

表3. 評価対象事例について

\begin{tabular}{|c|c|c|c|c|c|c|c|}
\hline 住宅 & \begin{tabular}{|c|}
$\begin{array}{c}\text { 建筑年 } \\
\text { (年) }\end{array}$ \\
\end{tabular} & \begin{tabular}{|c} 
增改築年 \\
(年)
\end{tabular} & 家族構成 & $\begin{array}{c}\text { 身体状況 (介護認定の有無 } \\
\text { サーヒヒス内容 }\end{array}$ & $\begin{array}{c}1 \text { 階面皘 } \\
\left(\mathrm{m}^{\prime}\right)\end{array}$ & $\begin{array}{c}\text { 数地面榡 } \\
\left(\mathrm{m}^{2}\right)\end{array}$ & $\begin{array}{l}\text { 街路の } \\
\text { ある角 }\end{array}$ \\
\hline $\mathrm{A} 1$ & 1974 & 1999 & 母80代+夫婦+子1 & 目:介護 $4 /$ /巡・ヘ・デ・看 & 111 & 222 & 鱼地 (北/東) \\
\hline $\mathrm{A} 2$ & 1976 & 1993 & 70 代 & 妻:介護 $4 / \bar{\tau} \cdot$ 看·入 & 104 & 273 & 鱼地 (北/西) \\
\hline $\mathrm{A} 3$ & 1972 & 2000 & 高新会夫婸701 & 妻: 車椅子生活·要介護 & 85 & 258 & 南 \\
\hline B1 & 1975 & & & 健康 & 73 & 219 & 南 \\
\hline $\mathrm{c1}$ & 1975 & - & 夫授 & 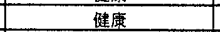 & 84 & 275 & 角地(北/東) \\
\hline $\mathrm{C} 2$ & 1973 & - & 夫婦80代 & 夫:介護 $2 / \bar{\tau}$ & 77 & 280 & 東 \\
\hline $\mathrm{C} 3$ & 1973 & & 夫㴔 $(70$ & 夫:足をひきずる/妻: 喘息 & 87 & 308 & 角地(北/西) \\
\hline $\mathrm{C4}$ & 1998 & - & 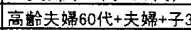 & 夫:持病のため外出困難 & 98 & 280 & 西 \\
\hline $\mathrm{C5}$ & 1991 & - & 夫婂70代 & 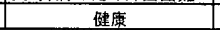 & 98 & 272 & 西 \\
\hline
\end{tabular}

価」は現在の居場所、「可能性評価」は介護や支援の視点からみて望 ましいと考えて想定した居場所、について各項目の評価を行った。 （が多いほど、介護・支援をする側、される側の両者にとって負担 の軽い住宅として高く評価される。

\section{6-2. 評価の結果}

各住宅に扔ける「現状評価」と「可能性評価」について図 6 に示 す。特徴的なものを取り上げると、A1は北側街路にも関わらず、在 宅介護のしやすさを考慮して街路側に高齢者の居場所を設けている (図 4)。居室の街路側と南側の 2 面に空を設えることで、街路の様子 と庭の眺めの両方を選択して楽しむことができる。また、外から中 の様子が感じられる点で、地域支援の面でも高く評洒される。A1 と

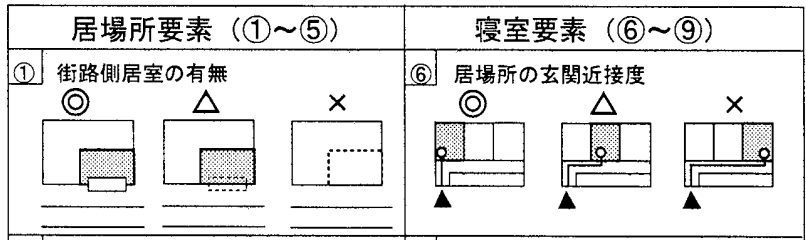

(2) 居場所から街路の様子を眺められる(7) 玄関から居場所へ行く時、

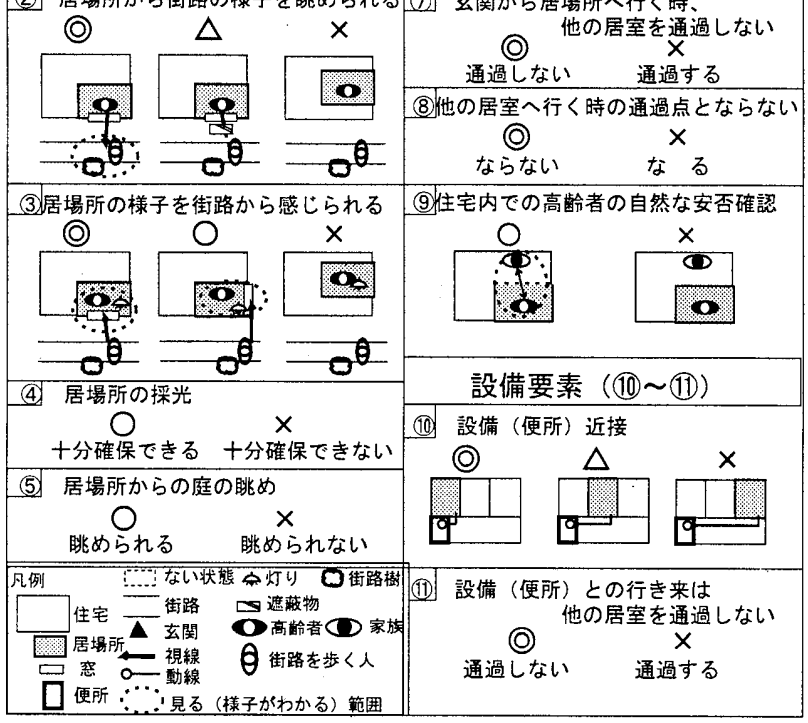

図5.在宅介護と地域支援の視点からみた住宅評価項目（○非常に有効、有効、 $\triangle$ 改善が必要 (1)(2))・どちらともいえない(5)(10)、X非有効)

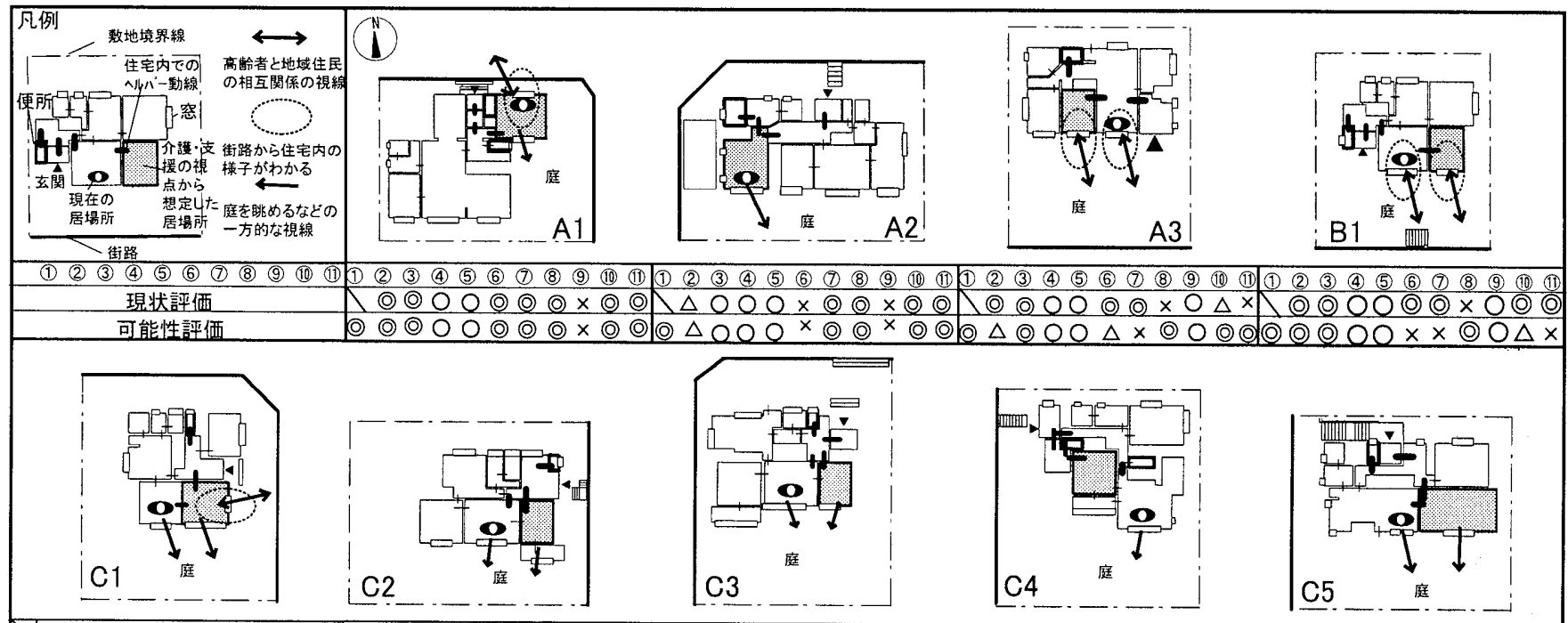

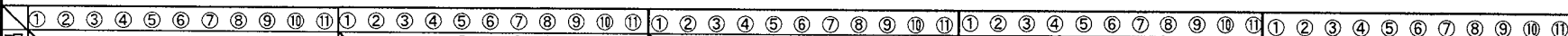
現 $\times \times 00 \times \times 00 \times \times 1 \times \times 00 \Delta 000 \Delta 0 \times \times \times 00 \Delta 0 \times 0 \Delta 0 \times \times \times 00 \times 00000 \times \times 00 \times 0 \times 000$

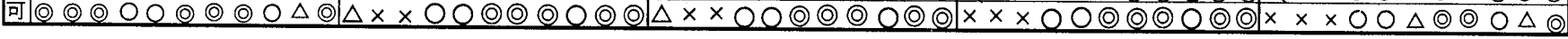

図6. 在宅介護と地域支援の視点からみた各住宅平面の「現状評価」と「可能性評価」(11～(11)評価項目は図5を参照のこと) 
A2 は、ヘル゚ーが、玄関ホールや廊下から直接高龄者の居場所に行くこと ができ、家族の生活領域に立ち入ることがない点で高く評価される。

南入り住宅 $(\mathrm{A} 3 \cdot \mathrm{B} 1)$ は、「現状評価」「可能性評価」ともに、外 部との関係を持ちやすく地域支援の受けやすさの点で評価されるが、 在宅介護ではへルパーが居間などの家族団緗の場を行き来するので、へ ルパーの動線を家族の生活領域と分離する工夫が必要である。

・Cタイプの全てが街路側に居場所を設けていないため「現状評価」 は低い。特にC5は、地域との関係を意識していないため、街路側に 居室は無く、街路から住宅内の様子はわからない。在宅介護をしや すい点では評価できるが、地域支援を受けづらい点で評価は低い (図 7)。一方、C1 は「可能性評価」でA夕仿と同程度評価でき、将 来的に介護や支援に対応しうる住宅であることがわかった（図 8)。 街路に面した空のある居室（現在客間）を要介護時に居場所に転用 できるように、住まい方に合わせた使い方のできる点を高く評価で きる。また、而住宅ともに、続き間があるため視認性と領域分離を 自由に行うことができるのも特徴として挙げられる。従来こうした 続き間は住戸計画の上であまり評価されていなかった部分であるが、 特にC1のように街路側居室と居間が続き間のような場合、本研究の 視点から庭側と街路側の雨方が見通せる点で改めて評価できる。

7.まとめ

本研究では、地域全体で高齢化の進む住宅地の高齢者を対象に調 査を行い、これからの住宅のあり方を検討するための新しい計画的 視点の提案について考察した。以下にその内容を要約する。

建設年：1991年

家族形態：夫婦のみ（夫 76 歳・妻 74 歳）身体状況：ともに健康

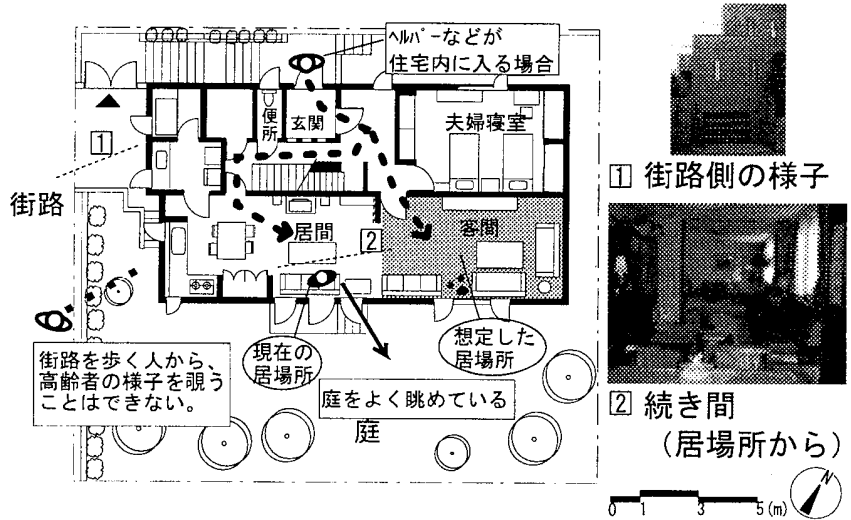

図 7. 在宅介護や地域支援の視点からみて評価の低い住宅事例（C5）

建設年: 1975 年

家族形態：夫婦のみ（夫 68 歳・妻 64 歳）身体状況：ともに健康

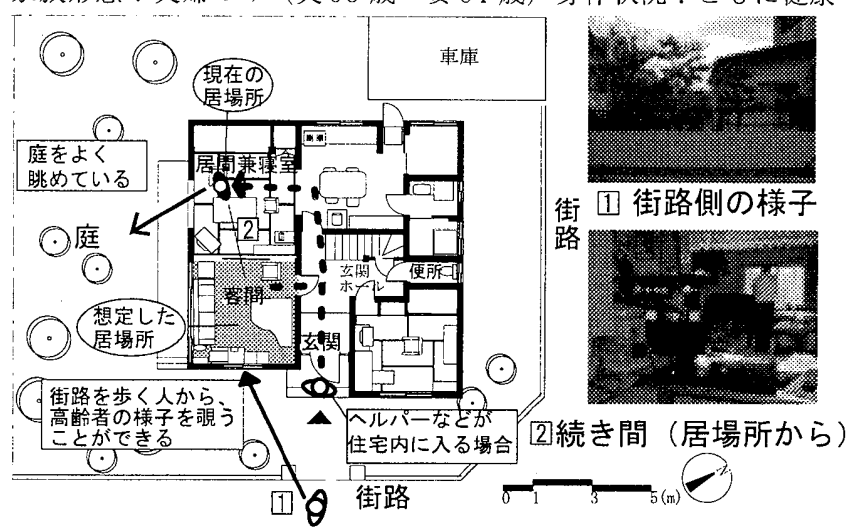

図 8. 在宅介護や地域支援の視点からみて評価の高い住宅事例（C1）
まず、居住実態の面からは、(1)現状では街路との関係を意識して 居場所を設える高齢者はほとんどいないが、そのことについて許容 する高齢者は1 ～2 割程度いる。特に、自力で外出困難な高齢者は、 「街路を歩く人を眺める楽しさ」や「外出のしやすさ」の点で高く評 価していることがわかった。(2)身体が不自由になると、居場所と寝 室を一体化する傾向がみられた。居場所となる居室と寝室を将来的 には一体的に利用することが可能な計画が必要である。

また、要介護者の居る住宅改造の事例からは、(1)住宅の街路側に 高齢者の居場所を設ける、(2)ルパーと家族の領域分離、(3)寝室・設 備の近接配置など、多くの工夫とともに本研究の視点である街路側 対応の計画がすでに実施されていることが明らかになった。

在宅介護や地域支援の視点からみた高龄者住宅の平面評価からは、 (1)「現状評価」では、南側に街路がある住宅の場合は外部との関係 を持ちゃすく、南以外の方角に街路がある住宅の場合は、外部との 関係を持ちにくい傾向がある。(2)「可能性評価」では、南入り住宅 はへパーの動線を家族の生活領域と分離する工夫を行うとよいこと、 (3)街路側に空のある居室があり、広めの立関林や廊下などでへル゚ー との領域分離をしやすい住宅プランの評価が高いこと、(4)続き間空間 の有効性、などが明らかになった。

総じて、住宅の街路側に高齢者の居場所があることは、在宅介護 の面では、要介護者の生活意欲促進と介護する家族の心理的負担の 軽減につながり、地域支援の面では、住民による日常的な州ポートを 可能にすることが明らかになった。本研究において、在宅介護や地 域支援の面で、街路側居室の重要性が示唆された。また、事前に街 路側のあり方の重要性を知ることができれば、健康な高龄者も街路 側居室を許容する可能性があることがわかった。平面評価では、街 路側に空があって玄関から直接行き来できる居室があり、へル゚ーと家 族との領域分離をしやすい住宅プランが高く評価される。また、続き 間の活用による新しい居場所対応型住宅平面の開発可能性も高い。 このように、街路側を意識した居場所設営、外出・訪問の容易さ、 第三者動線の入り込みなどに対応した新しい概念による高齢者向け 住宅計画理論の確立が重要である。

本研究を遂行するにあたり北海道大学䢐嶋教授に指導を得た。 記して謝意を表します。

\section{参考文献}

1) 矢野めぐみ、野口孝博：戸建住宅における在宅高龄者の日常の居場所を中心とする 生活行動様式、日本建築学会大会学術講演梗概集、pp. 325-326、1999.9

2）片岡正喜、鉿木義弘、中武啓至：住生活抛点の存在確認と拠点のとられ方、 日本建築学会計画系論文集、第 460 号、pp.71-80、1994.6

3）古賀紀江、高橋尉志：一人暮らしの高龄者の常座をめぐる考察、 日本建築学会計画系論文集、第494 号、pp. 97-104、1997.4

4）橘 弘志、高橋磨志:一人暮らし高龄者の生活に抢ける住戸内外の関わりに関する考察、 日本建築学会計画系論文集、第 515 号、pp.113-119、1999.1

5）植松徽治、野口孝博：可建住宅における居住者の日照·方位観と平面構成、 日本建築学会大会学術变演梗概集、pp. 241-242、2001.9

6）耶雲恵、野口孝博：街路等の外部領域を意識した戸建住宅の開口部形状と配置形式、 日本建築学会大会学術濖演梗概策、pp. 1-2、2001.9

7）馬場昌子+福祉医燎建築の連携による住居改善研究会、

高龄者・障害者のための住居改善、株式会社学芸出版社、2001

8) (株) U-E.P. 注: バリアフリーの家 新筑 \&改築実例集、永岡觜店、2001

注1）アンケートて、「夏冬のふだんの過ごし方について」というアンケー項目に対する回答を基 にしたものである。冬は雪の問題で外出を撜える高龄者が多いことから、本来の生活スタイ ルをあらわすのは夏と考え、「夏のふだんの過ごし方」を取り上け゚た。

注2「安心感」は、「居場所を街路側に設けることについて」というアンケー項目に対する回答 で、「声かけのきっかけが增えたり、見守られているような安心感が持てるのでよい」のこと。 注 3）「楽しさ」は、「居場所を街路側に設けることについて」というアンケート項目に対する回 答で、「街路を歩く人を見るのが楽しいのでよい」のこと。

[2002年 4 月18日原稿受理 2002年 7 月23日採用決定 ] 